Documenta \& Instrumenta

ISSN-e: 1697-3798

http://dx.doi.org/10.5209/rev_DOCU.2017.v15.56199

\title{
¡Arganda ya es villa real!: estudio documental de la carta de privilegio concedida por Felipe II (1583)
}

\author{
Juan Carlos Galende Díaz ${ }^{1}$
}

Recibido: 7 de septiembre de 2016 / Aceptado: 10 de mayo de 2017

Resumen. El año 1583 supuso un momento clave en el devenir histórico de Arganda del Rey. En tal fecha, concretamente el 23 de abril, Felipe II despacha una carta de privilegio por la que, eximiéndola de la dignidad arzobispal de Toledo, concede a esta localidad madrileña la jurisdicción real a la vez que el título de villazgo. En el presente artículo se realiza un estudio de carácter documental, centrado en el análisis paleográfico y diplomático de la citada carta de privilegio, atesorada en el Archivo de la Ciudad de Arganda del Rey.

Palabras clave: Paleografía; Diplomática; Felipe II; Arganda del Rey; carta de privilegio; historia moderna.

[en] Arganda is now a royal villa!: a diplomatic study of the privilege granted by Philip II (1583)

Abstract. 1583 was a key year in the historical development of Arganda del Rey. On April $23^{\text {rd }}$ of
that year, Philip II dispatched a privilege which, exempting the dignity of archbishopric of Toledo,
gave both royal jurisdiction and the title of villazgo to that locality. In this article a documental study
is carried out, focusing on the paleographic and diplomatic analysis of the said privilege, held at the
Archive of la Ciudad de Arganda del Rey.

Keywords. Palaeography; Diplomatics; Philip II of Spain; Arganda del Rey; privilege; modern history.

Sumario. 1. Noticias históricas. 2. La escritura. Estudio paleográfico. 3. El documento. Estudio diplomático.

Cómo citar: J. C. Galende Díaz, “AArganda ya es villa real!: estudio documental de la carta de privilegio concedida por Felipe II (1583)”, Documenta \& Instrumenta, 15 (2017), pp. 25-43.

1 Universidad Complutense de Madrid (España)

E-mail: jgalende@ucm.es 
En el Archivo de la Ciudad de Arganda del Rey ${ }^{2}$ se atesora una pieza documental de innegable valor para la historia de esta localidad madrileña: la carta de privilegio concedida en 1583 por Felipe II eximiéndola de la jurisdicción arzobispal y confiriéndola tanto la condición de villazgo como la jurisdicción real ${ }^{3}$.

\section{Noticias históricas}

Todo parece indicar que desde mediados de la centuria decimocuarta la población aleana se consolida y, paulatinamente, va creciendo ${ }^{4}$. Dos siglos después, las edificaciones se levantan a ambas orillas del camino real, estabilizando un entorno que permanecerá durante largo tiempo. Por esta época, Arganda ya era un lugar de señorío perteneciente al Arzobispado de Toledo, lo que perduraría hasta $1580^{5}$. En noviembre de este año Felipe II, con la finalidad de mejorar la hacienda real y amparándose en una bula del papa Gregorio XIII que le autoriza a tomar cualquier lugar eclesiástico, la desmiembra del citado arzobispado, otorgándola la condición de villa de realengo; sin embargo, un mes después, por necesidades recaudatorias, el Rey Prudente la vende al señor de Campo Real Nicolás Grimaldo, quien posteriormente la traspasa a Melchor de Herrera, señor de Carabanchel, y, por último, pasa a manos del señor de Carabaña, Sebastián de Santoyo ${ }^{6}$.

No obstante, en septiembre de 1581, el hijo de Carlos V ofrece a los vecinos argandeños la posibilidad de recuperar la jurisdicción de su villa previo pago de diez mil doscientos ducados, cantidad que había abonado su poseedor actual ${ }^{7}$. Deseosos de libertad, en junio del año siguiente, aceptan la propuesta, consiguiendo el dinero de dos prestamistas madrileños, Francisco de Matallana y Pedro Menéndez de Salvatierra. De ahí que Felipe II confiera de nuevo a Arganda la condición de villa de realengo en febrero de $1583^{8}$. Sin embargo esta circunstancia perdura tres décadas, pues en 1613, debido a las deudas contraídas, es adquirida por el duque de Lerma, Francisco de Sandoval y Rojas ${ }^{9}$, a pesar de las quejas vecinales, que ocasionan la

2 Desde estas líneas quiero agradecer a D. Julio Cerdá Díaz, director de este Archivo Municipal, todas las facilidades e información que me ha prestado para la elaboración del presente estudio.

3 Archivo Municipal de Arganda (AMAr), sign. 009700070001 (http://archivo.aytoarganda.es/digital/Document.aspx?id=009700070001).

4 Según parece, el primer asentamiento data de la época de la dominación árabe, núcleo poblacional que se afianzará con la Reconquista y ulterior repoblación cristiana.

5 Prácticamente perteneció al Arzobispado toledano durante más de 400 años. Con probabilidad así fue desde que el emperador Alfonso VII hiciera donación del señorío de Alcalá y su tierra, una vez que se reconquistó en el primer tercio del siglo XII, al arzobispo don Raimundo, sucesor de don Bernardo. A. BENITO ALFARO, Arganda del Rey, Madrid, 1890, pp. 20-21.

6 El motín de Arganda. Estudio y documentación, Arganda del Rey, 1995, pp. 9-10.

7 Conforme expone José Barros "Si por independencia entendemos su separación del concejo de Alcalá y su conversión en villa, Arganda logró la independencia el 25 de noviembre de 1580. Si por independencia entendemos la libertad de los argandeños para elegir a sus autoridades municipales, Arganda logró su independencia el 12 de septiembre de 1581". J. BARROS CAMPOS, Arganda del Rey, cuna de Miguel de Cervantes, Madrid, 2010, pp. 19-20. En esta monografía también se pueden consultar otros apuntes históricos de Arganda.

8 J. A. de la TORRE BRICEÑO, A. MUR RAURELL, J. BARRO CAMPOS y M. J. HUELVES MUÑOZ, $L a$ Casa del Rey. Cuatro siglos de historia, Madrid, 1997, pp. 30-33.

9 El duque de Lerma pagó por cada vecino 16.000 maravedís, solventando el débito de los 10.200 ducados. A. BENITO ALFARO, Arganda del Rey, pp. 22-23. 
algarada conocida con el nombre del "motín de Arganda" ${ }^{10}$. En 1650, al fallecer sin herederos varones el nieto del duque de Lerma, Arganda volvió a ser villa realen$\mathrm{ga}^{11}$.

Será también a lo largo del siglo XVII cuando la Compañía de Jesús se establezca en tierras argandeñas. Poco a poco adquieren un tercio de las haciendas dedicadas al cultivo del viñedo, sin duda, las mejores, con un marcado sentido mercantil. Desde este momento, el entorno y el ambiente de la villa se acomoda a la nueva actividad; sirva de ejemplo que, conforme a las respuestas recogidas en el Catastro de la Ensenada, en 1752 Arganda contaba con 102 casas que tenían entre sus dependencias una bodega vinatera, lo que suponía cerca del $20 \%{ }^{12}$.

Cuando en 1764 los jesuitas son obligados a abandonar la localidad madrileña, el comercio del vino recaerá en un pujante círculo de propietarios que ejercerán su dominio político y económico a partir de la centuria decimonónica ${ }^{13}$.

La contemporaneidad trajo mejoras (construcciones, industrias, red de transportes...), lo que conllevó un crecimiento económico y demográfico, culminado en el siglo actual, en el que Arganda del Rey se ha convertido en "la capital del sureste madrileño" ${ }^{14}$.

\section{La escritura. Estudio paleográfico}

\subsection{Introducción}

La propia crisis de la escritura "gótica" constituye el punto de arranque de su sustitución por los modelos "humanísticos". La excesiva proliferación y sobreabundancia de tipos dentro de la escritura "gótica" provocará, en toda Europa, una especie de barroquismo gráfico en las formas más singulares de estos caracteres, cada vez menos funcionales, tanto por su complicación como por su dificultad ${ }^{15}$.

El manierismo de los escribas que, con la finalidad de incrementar sus beneficios económicos, trazan letras sugerentes, pero de rasgos semejantes, ocasionará un auténtico confusionismo gráfico, frente al cual, desde mediados del siglo XIV, los primeros humanistas se oponen de forma decidida, preocupándose por la mejora de la hechura escrituraria.

Quizá, en este sentido, haya que considerar a Petrarca iniciador de la reforma gráfica, pero fueron sus discípulos quienes imitaron y desarrollaron el método de su maestro. Francesco Petrarca reclama unas grafías claras, sobrias, prácticas, precisas y límpidas, que entren por los ojos sin esfuerzo, por lo que se aparta de la

10 Véase el interesante y documentado estudio de J. A. de la TORRE BRICEÑO, "La venta de la villa de Aranda al duque de Lerma", Anales Complutenses, 14 (2002), pp. 61-76.

11 M. RODRÍGUEZ-MARTÍN Y CHACÓN, Arganda del Rey. Apuntes para su historia, Madrid, 1980, pp. 130328.

12 http://www.ayto-arganda.es/portalArganda/p_20_contenedor1.jsp?seccion=s_fdes_d4_v2. jsp\&codbusqueda $=11 \&$ language $=$ es\&codResi $=1 \&$ layout $=p \_20 \_$contenedor $1 . j$ sp \&codAdirecto $=23$

13 M. RODRÍGUEZ-MARTÍN Y CHACÓN, Arganda del Rey. Apuntes para su historia, pp. 421-519; y DOCUMADRID, Arganda del Rey, Madrid, 2003, pp. 43-137.

14 Hasta el año 1996 el nombre de este municipio era "Arganda", fue entonces cuando pasó a denominarse "Arganda del Rey".

15 E. CASAMASSIMA, "Lettere antiche: Note per la storia della riforma grafica umanistica", Gutenberg Jahrbuch, 39 (1964), pp. 13-26. 
letra fatigante y artificiosa, por lo relajada y exuberante en rasgos, cual es la de los copistas o más bien pintores de nuestra época, que embelesa a la vista aunque acaba por dañarla y cansarla, como si hubiera sido inventada para otro fin distinto de leer ${ }^{16}$. Consecuentemente, para llevar a cabo sus ideales y proyectos, estudia y emplea la "littera antiqua", que en su época suponían "romana", pero en realidad era la "minúscula carolingia" de los siglos IX al XII. Ya, en 1355, agradece a Bocaccio el regalo del códice las Enarrationes in Psalmos, de San Agustín, escrito en letra "carolina", manifestándole que cuando clavo los ojos en él, a modo de golondrinas sedientas, no logro retirarlos hasta no haber saciado la sed ${ }^{17}$.

En ninguna otra parte el terreno y condiciones eran tan propicias como en Italia para realizar estos cambios gráficos. Precisamente es en los círculos humanísticos de Florencia donde, por estas fechas, se establece una corriente de innovación escrituraria que culminará en la letra "humanística caligráfica", reservada tanto a libros como a documentos de cierta solemnidad y relevancia ${ }^{18}$. De estos momentos, además de los citados autores, destacan Coluccio Salutati, Niccolo Niccoli y Poggio Bracciolini, siendo este último quien, a principios del siglo $\mathrm{XV}$, la lleva a su perfección y acabamiento en el Códice Laurenziano Strozziano 96, que contiene el tratado De Verecundia, primer manuscrito datable en escritura "humanística"19.

Aparte de la escuela florentina hubo otras decisivas en la reproducción de códices, a las que se difundió con rapidez la "humanística"; entre ellas, las instaladas en Roma, Urbino, Ferrara, Nápoles, Bolonia, Verona, Mantua y Milán ${ }^{20}$. Cuando estas muestras humanístico-renacentistas consiguen expandirse por toda Italia con un alto grado de canonización y tipificación se difunden por Europa durante el siglo $\mathrm{XV}$, produciéndose a lo largo de esta centuria, según los estados y territorios, nuevas "gótico-humanísticas", que desembocarán en las típicas "humanísticas" de las centurias siguientes.

En la Península Ibérica se siguen modelos italianos, que se introducen, por razones políticas de dependencia, primero en la Corona de Aragón, durante el reinado de Alfonso V. En Castilla, esta escritura, se va asentando en diferentes etapas: sus inicios tienen lugar tras la unificación peninsular $\mathrm{y}$, de modo definitivo, a lo largo del reinado de Carlos $\mathrm{V}^{21}$. De este modo, las grafías "humanísticas" hicieron su entrada triunfal en todas las cancillerías, curias, escuelas y escribanías, no sólo por su sencillez y facilidad de trazado, sino también por su singular belleza, nitidez y legibilidad. Por esas mismas razones tiene gran aceptación entre el pueblo, y lo

16 A. PETRUCCI, "La scritura di Francesco Petrarca", Studi Medievali, 8 (1967), pp. 934-939.

17 J. C. GALENDE DÍAZ, "La escritura humanística en la Europa del Renacimiento", Espacio, Tiempo y Forma. Historia Medieval, 11 (1998), pp. 198-199.

18 En un principio, la minúscula "humanística" fue una escritura de elite, cuya difusión mantiene gran paralelismo con la cultura docta de la que era expresión; no se divulgaría hasta que no fue introducida en los centros escriptorios y en las escuelas, a la vez que se abriría la posibilidad de proceder a una modificación del canon. M. L. MANDINGORRA LLAVATA, "La escritura humanística en Valencia: su introducción y difusión en el siglo XV”, Estudis Castellonencs, 3 (1986), pp. 5-94.

19 J. STIENNON, Paléographie du Moyen Age, Paris, 1973, p. 123.

20 C. ÁLVAREZ MÁRQUEZ, Escritura latina en la Edad Moderna: la escritura humanística, Sevilla, 1995 , pp. 63-64.

21 I. RUIZ ALBI, "La escritura hispano-humanística moderna", en Paleografia y escritura hispánica, Madrid, 2016, pp. 217-236; y "La escritura humanística documental durante el siglo XVI. El panorama castellano a través de la documentación de Cámara de Castilla (Archivo de Simancas)", en Paleografía III: La escritura gótica (Desde la imprenta hasta nuestros dias) y la escritura humanística, Madrid, 2011, pp. 47-71. 
mismo sucede en la escritura de libros o caracteres de imprenta, que son simple adaptación ${ }^{22}$.

\subsection{Análisis paleográfico}

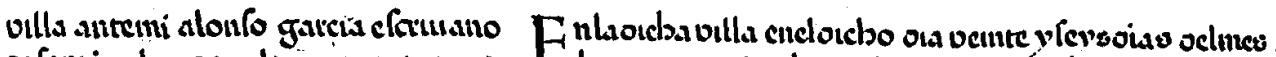

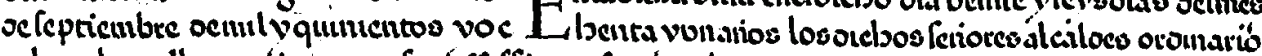

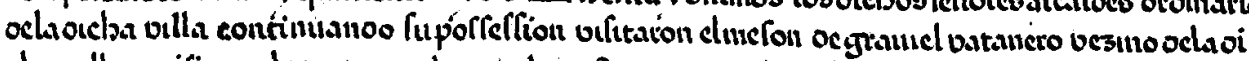

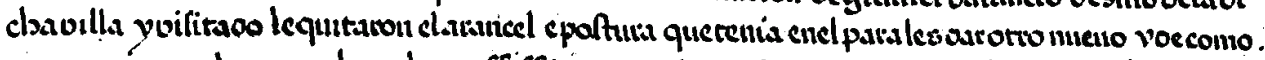

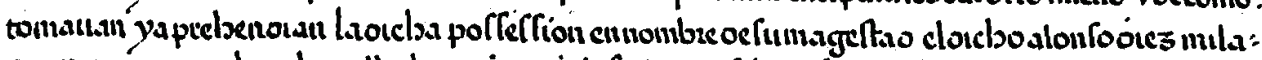

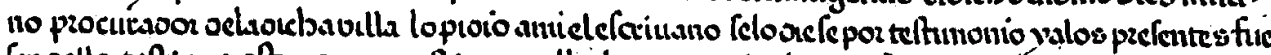

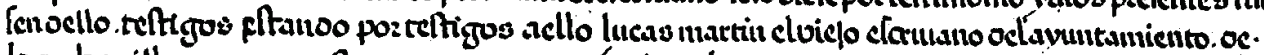

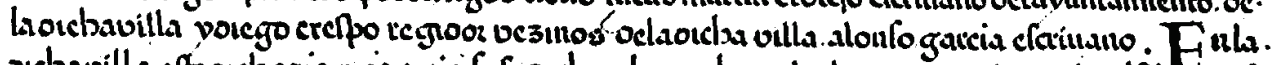

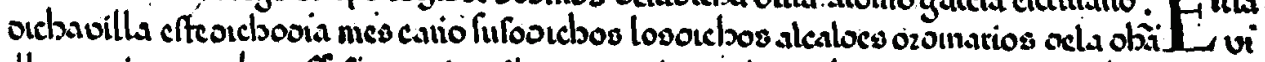

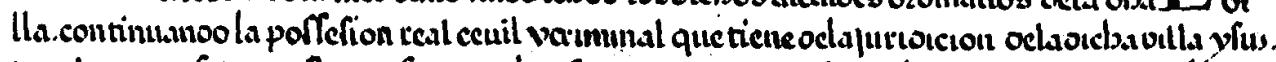

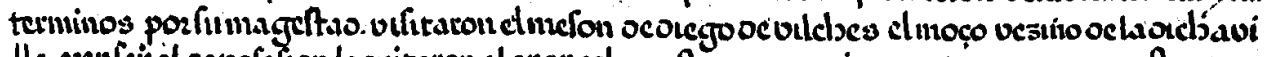

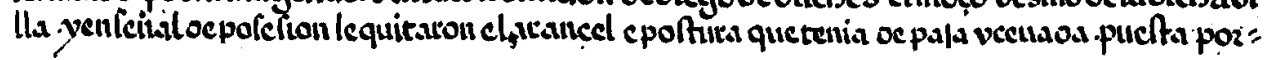

La presente carta de privilegio está escrita con caracteres "humanísticos" redondos o formados, si bien conserva algunos elementos gráficos del modelo "gótico". Esta escritura "humanística" redonda no es sino la "carolina" restaurada en su sustancia $\mathrm{y}$ en muchos de sus accidentes, de tal manera que su imitación es tan manifiesta que raya en el servilismo.

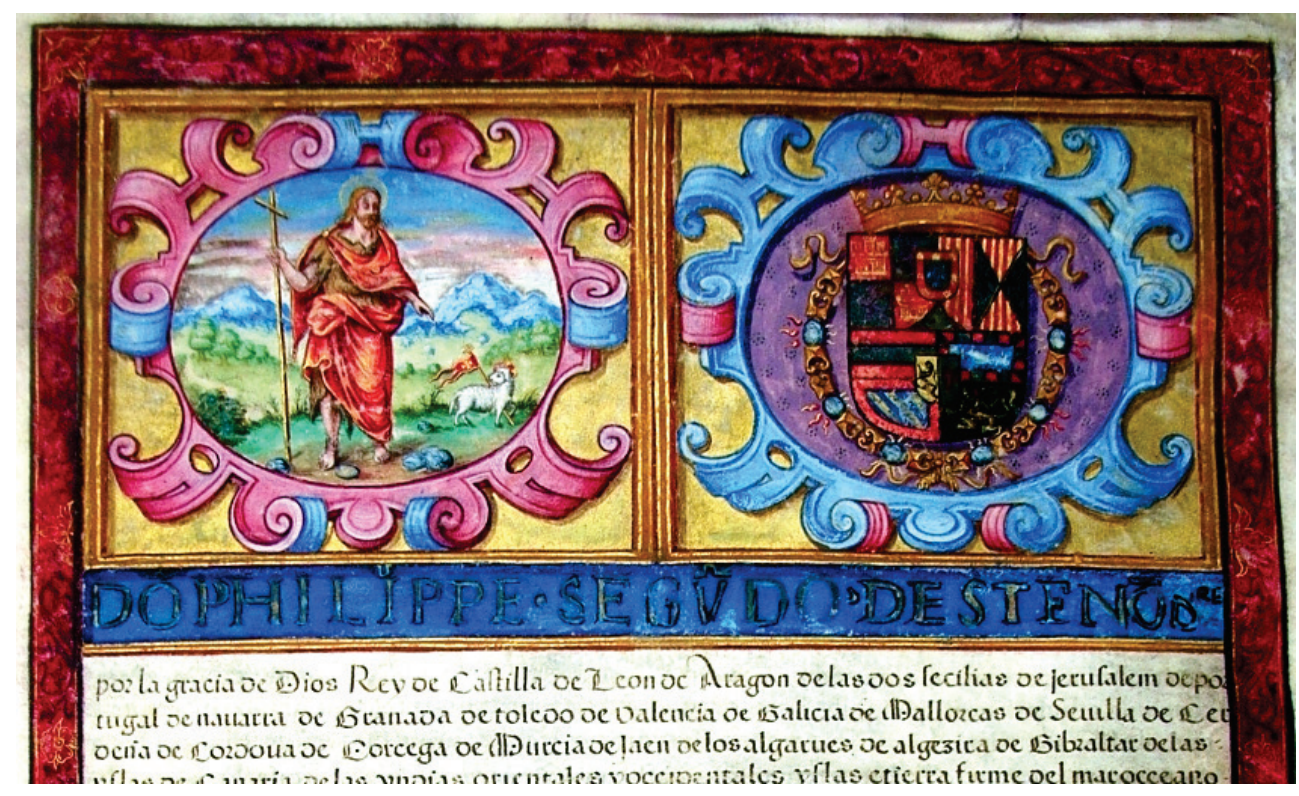

22 Con el paso del tiempo, toda la colectividad de escribientes tenderá a utilizarla de manera usual. E. RUIZ GARCÍA, "La escritura humanística y los tipos gráficos derivados", en Introducción a la paleografia y la diplomática general, Madrid, 1999, pp. 164-165. 
Se trata de un ejemplar pergamináceo, en forma de cuadernillo (43’5 x 29 cm.), compuesto por 20 bifolios (40 hojas), de los que el primero sirve de cubierta, tanto para la tapa superior ${ }^{23}$, como para la inferior. La escritura, trazada con tinta oscura -en ocasiones, retintada-, discurre a línea tirada, de forma opistógrafa, por las primeras 33 hojas (excepción hecha de la cubierta), quedando cinco folios en blanco al final, salvo unas anotaciones en el margen inferior, a modo de probationes pennae, en dos de ellos ${ }^{24}$.

La numeración de este ejemplar, posterior a su hechura, se localiza con dígitos árabes en el extremo superior derecho del anverso de cada folio. Asimismo, presenta calderones marginales para destacar fragmentos del texto, los cuales, en ocasiones, aparecen subrayados. Tanto estos signos y marcas de atención, como algunas adiciones interlineadas o al margen, también fueron realizados en un momento más tardío a la confección del manuscrito, producto de la corrección del mismo por parte de un oficial subalterno ${ }^{25}$.

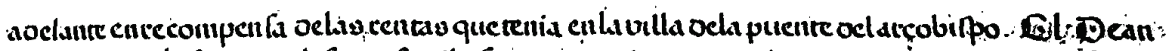

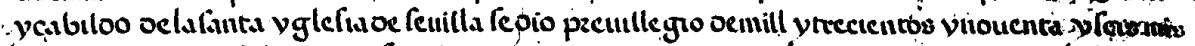

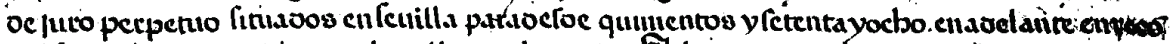

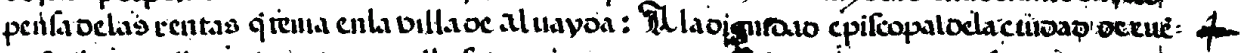

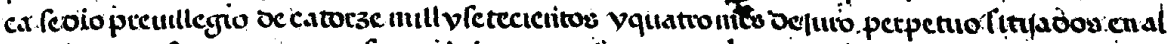

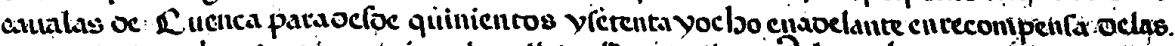

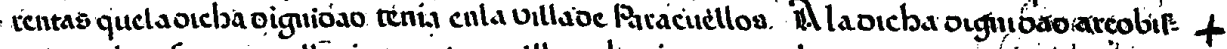

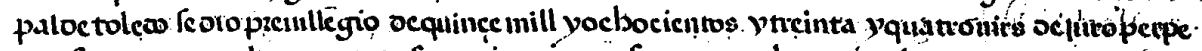

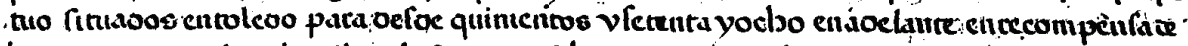

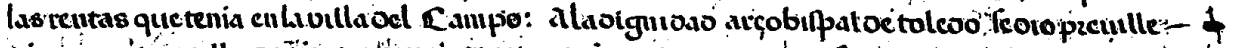

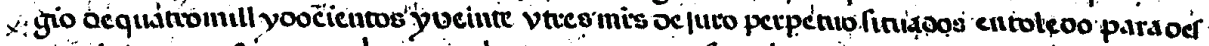

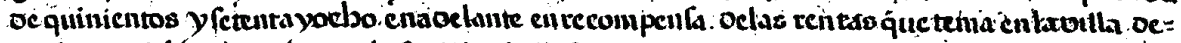

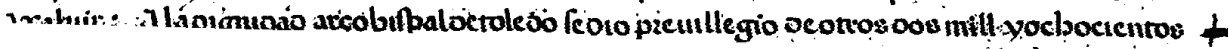

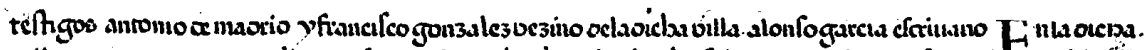

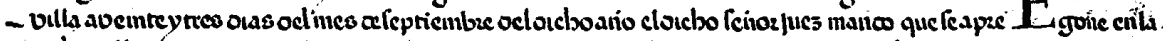

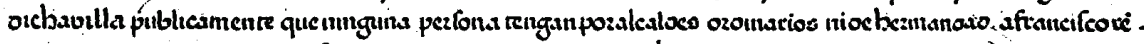

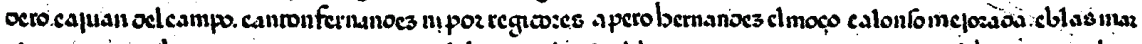

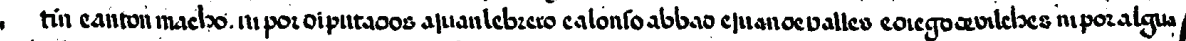

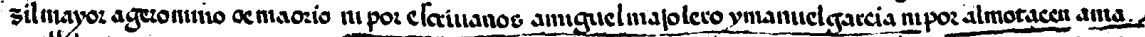

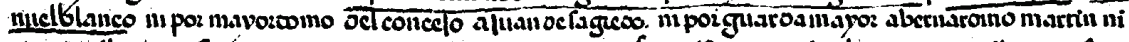

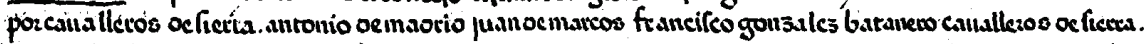

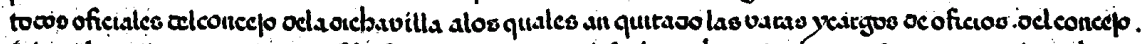

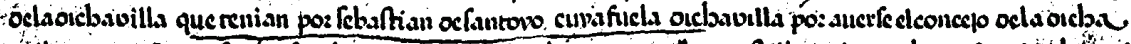

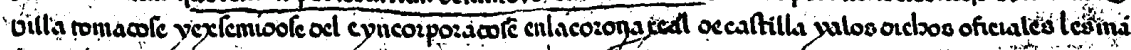

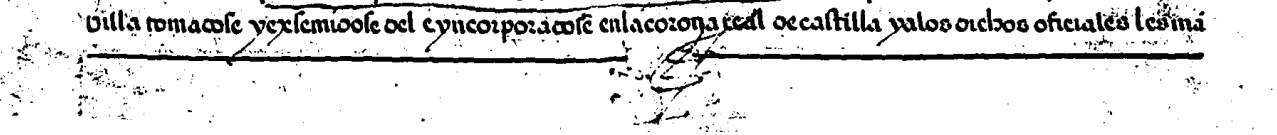

Desde el punto de vista paleográfico, las principales características, de forma genérica, que adquiere este documento, en cuanto a su escritura, son la proporción, la regularidad y la redondez de su rasgos; la nitidez y claridad gráfica a base de un

23 Bellamente iluminada, con orla e ilustraciones polícromas.

24 En el primero de ellos se puede leer: In principio erat verbum et verbum erat apud Deum, et Deus erat verbum, mientras que el otro fragmento escrito es: Verum carum.

25 Este texto está redactado con letra "humanística" cursiva, más apropiada para esta labor, en la que se requiere más agilidad y, en consecuencia, menos esmero caligráfico. 
trazo sencillo y ágil, de modo que su "ductus" desarrolla formas verticales y curvaturas sin adornos, ni arranques y acabados ornamentales; reducción de abreviaturas y buena separación de las palabras.

La morfología de las letras que conforman su alfabeto no plantea ningún problema de identificación, únicamente cabe advertir cierta dificultad en algunas mayúsculas, como la $\mathrm{A}, \mathrm{B}, \mathrm{C}, \mathrm{E}$ y $\mathrm{M}$.

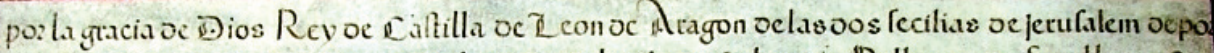

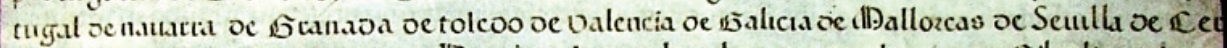

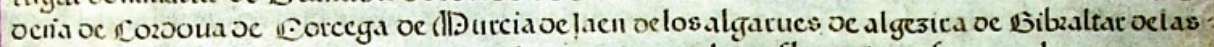

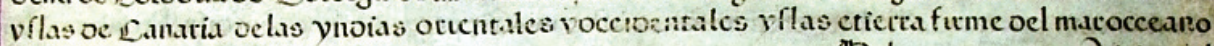

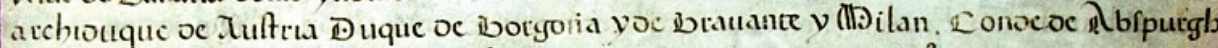

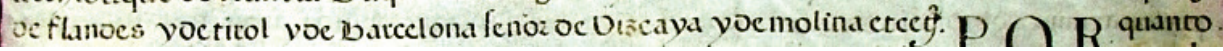

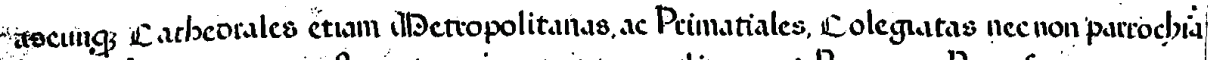

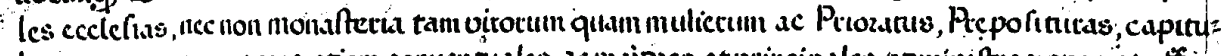

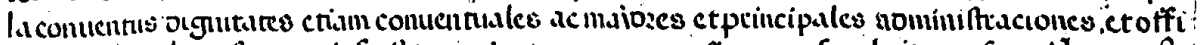

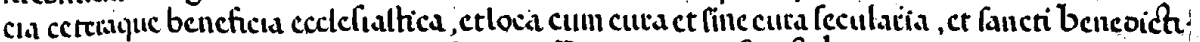

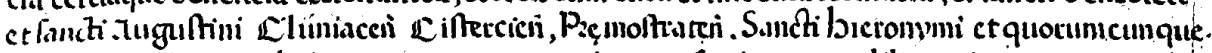

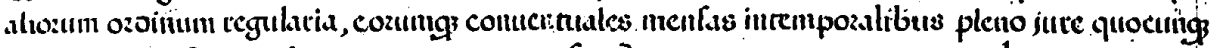

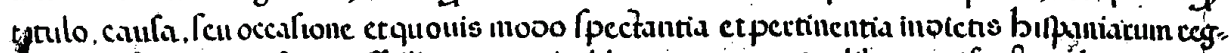

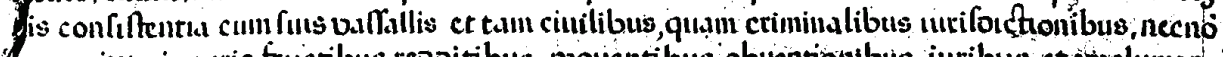
Inctumixto impetio fructibus teooitibus, pzouentibus obuentionibus, iuribus etemolumen:

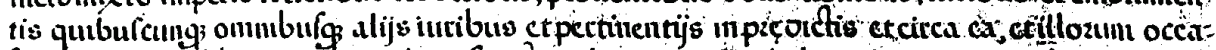

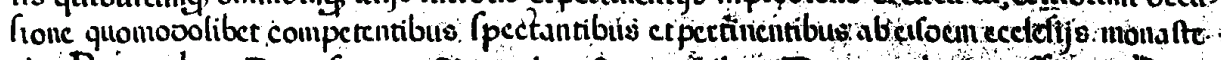

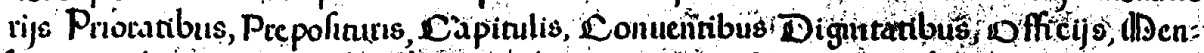

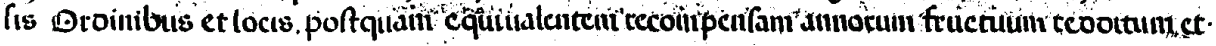

Respecto a las letras minúsculas, se pueden realizar algunos comentarios: la grafía "d" adquiere una forma uncial, con el astil inclinado a la izquierda; la vocal "i", de altura media, puede llevar el punto encima, aunque esta característica no es constante; la "o", normalmente, presenta sólo su rasgo discoidal, aunque, en ocasiones, se le hace preceder de un segmento semicircular; la " $r$ " alterna la hechura "redonda" con la "cuadrada", la mayoría de las veces siguiendo las leyes enunciadas por Wilhelm Meyer a comienzos del siglo XX en lo tocante a la letra precedente, según tenga convexidad o no hacia la derecha; la "s" puede presentar dos contornos, si es final de palabra adquiere la disposición de "doble curva", mientras que en cualquier otro lugar adopta el perfil de "s alta"; la "u" y la "v" se emplean indistintamente, al margen del sonido propio y exclusivo que poseen en la actualidad, prefiriéndose la primera forma cuando es una de las letras intermedias del vocablo, y reservándose la segunda para cuando es inicio de palabra; por último, la " $z$ " también puede configurarse de dos maneras, bien en forma minúscula, bien prolongando su caído y adoptando la estructura del numeral "3", que es la más habitual.
d: $\quad \partial$
i: 1 i
o: 06
r: $2 r$
s: $5 \Gamma \quad$ u-v: $4 \cup v$ z: $z 3$ 
En lo relativo a los nexos, junto a los de inspiración "carolina": "ct", "sp" y "st", se incluyen algunos que son típicamente "góticos", formados por la unión de dos curvas contrapuestas, las cuales se yuxtaponen en el trazo que las une: "do" y "de". Pero, sin duda, la característica fundamental es la individualización de las letras dentro de cada palabra, sin formar ligados.

$$
\text { ct: } \text { of sp: } \beta \text { st: } \mathbb{t}
$$

do: as de: $\partial p$

En cuanto al sistema braquigráfico se puede comentar, según se ha expuesto con anterioridad, que son pocas las palabras abreviadas, dándose la peculiaridad de que, en un cierto porcentaje, se suprime la nasal, y más si ésta es la última letra del renglón.

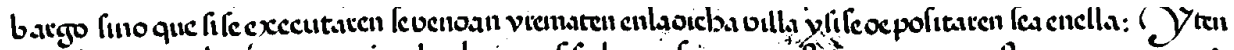

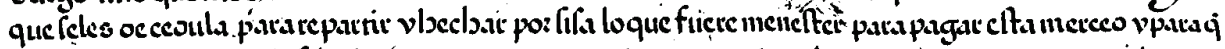

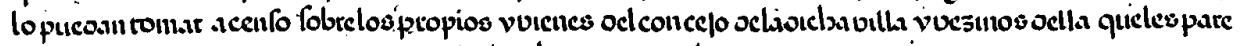

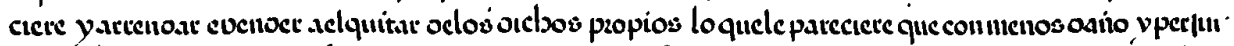

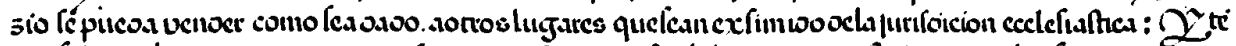

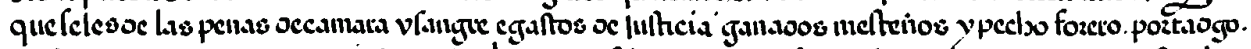

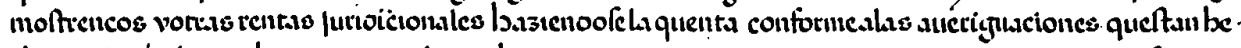

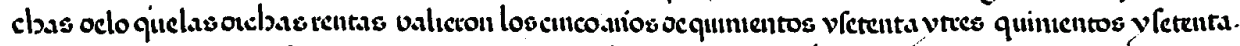

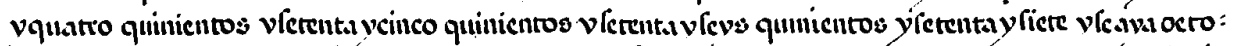

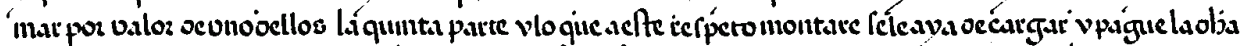

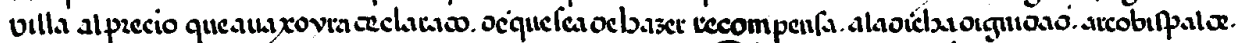

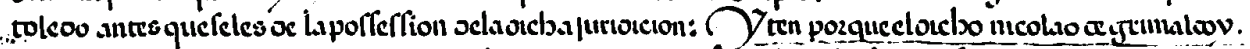

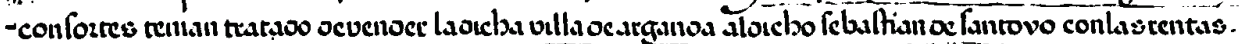

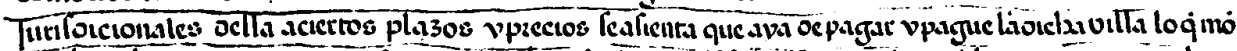

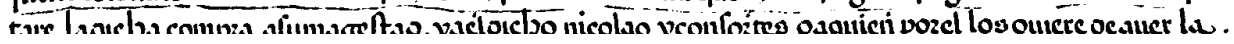

El signo abreviativo de carácter general suele ser un trazo, bastante corto y exiguo, que se coloca encima de la sílaba afectada. Puede tener la hechura de un punto o de línea, más o menos recta.

Apenas se emplean los signos abreviativos de naturaleza especial o específica, es decir, con valor propio. En este apartado, sólo se utilizan tres: uno para la sílaba "por", conformado por un rasgo horizontal que parte el caído de la letra "p" hacia su zona central; otro para la sílaba "bis", constituido por una raya que corta el astil de la grafía "b"; y el tercero para la sílaba "que", formado por un trazo peculiar que bisela el caído del carácter "q".

$$
\text { por: } f \text { bis: } t \text { que: } \phi
$$


Las abreviaturas se pueden configurar tanto por el sistema braquigráfico de suspensión, es decir, en las que falta, al menos, la última letra, como de contracción, en la que se elide alguna letra intermedia, pero mantienen la inicial y la final. Es oportuno indicar que, en ciertas ocasiones, las grafías que componen las abreviaturas adoptan, materialmente, la forma conocida con el nombre de "letras sobrepuestas", aunque se compendian siguiendo el método de síncope.

A continuación, y como conclusión de este apartado, se presenta un sumario de las abreviaturas insertas en este manuscrito:

- Suspensión:

aunq $=$ aunque; $c o=$ con; cobrare $=$ cobraren; comprare $=$ compraren; Domin $=$ Domingo; $\mathrm{e}=\mathrm{en}$; fuere $=$ fueren; Jua $=\mathrm{Juan} ; \mathrm{juridicio}=$ juridición; pertenece $=$ pertenecen; q= que; $\mathrm{u}=\mathrm{un}$; valia $=$ valían.

- Contracción:

adelate $=$ adelante; aqlla $=$ aquella; arçobpal $=$ arçobispal; arredadores $=$ arrendadores; cocedido $=$ concedido; coforme $=$ conforme; Cueca $=$ Cuenca; cuplido $=$ cumplido; $\mathrm{dho}=$ dicho; Herraz $=$ Herranz; mado $=$ mando; $\mathrm{mrs}=$ maravedís; nro $=$ nuestro; ocheta $=$ ochenta; queta $=$ quenta; recopesa $=$ recompensa; retas $=$ rentas; saciones $=$ sanciones; sactissima $=$ sanctíssima; seseta $=$ sesenta; $\operatorname{tatas}=\operatorname{tantas} ;$ tpo $=$ tiempo; treita $=$ treinta.

- Letras sobrepuestas:

$\operatorname{app}^{\mathrm{co}}=$ appostólico; $\operatorname{dig}^{\mathrm{d}}=$ dignidad; hebr $\mathrm{r}^{\mathrm{o}}=$ hebrero; jur $^{\mathrm{on}}=$ jurisdición; justi $^{\mathrm{a}}=$ justicia; $\mathrm{n}^{\mathrm{e}}=$ nombre; Mag $^{\mathrm{d}}=$ Magestad; $\mathrm{q}^{\mathrm{o}} \mathrm{s}=$ quentos; qui $^{\mathrm{o}} \mathrm{s}=$ quinientos; $\mathrm{T}^{\mathrm{do}}=$ Toledo; tros $^{\text {nos }}=$ términos; $\mathrm{v}^{\mathrm{a}}=$ villa .

\section{El documento. Estudio diplomático}

\subsection{Introducción}

Desde finales de la Edad Media se advierte una paulatina agilización en el campo documental, más significativa desde el período borbónico. La modernidad trae innovaciones en la forma y en la función administrativo-documental. Por una parte, en el medio público se escrituran las intervenciones, mientras que en el privado se incrementa la actuación notarial. El resultado de esta nueva concepción se puede resumir en una serie de manifestaciones, entre otras: consunción de tipos documentales de raigambre medieval, preeminencia de las fórmulas jurídicas sobre las solemnes, reducción de modelos diplomáticos y de la estructura formulística, aparición de nuevas cancillerías en la elaboración del documento real, plétora de escritos públicos incoados por autoridades delegadas, sistematización de los libros registros y establecimiento de los archivos ${ }^{26}$.

En este círculo, las cartas de privilegio son unos documentos solemnes, aparecidos en el siglo XII, cuyas características y tenor documental permanecen bastante 
constantes hasta la centuria decimoctava. De alguna manera, después del reinado de Isabel y Fernando vendrán a sustituir, o simplificar, al privilegio rodado ${ }^{27}$.

Se trata de un documento que se extiende teniendo a la vista la concesión real, aunque a veces se despachan directamente. Es decir, en el primero de los casos, el procedimiento de expedición consistía en la presentación, por parte del interesado, del citado otorgamiento por el que se dispensa la merced ante los funcionarios cancillerescos, quienes lo transliteraban en sus registros y, luego, lo rasgaban, asentando este extremo mediante $\operatorname{acta}^{28}$. Consecuentemente, estas cartas sirven de garantía jurídica de otros documentos anteriores.

Asimismo, estas cartas están expedidas en pergamino, por las Contadurías Mayores, en forma de cuaderno ${ }^{29}$. Por lo general, suelen tener una estructura diplomática completa, con todos sus elementos: invocación, preámbulo (no constante), notificación, intitulación, dirección (no explícita), exposición, disposición, cláusulas sancionativas y corroborativas, data y validación ${ }^{30}$. Las principales variaciones de este tipo documental en tiempos del Rey Prudente, en relación al reinado de su padre, estriban en la intitulación y en la cláusula corroborativa relativa al anuncio de la validación, pues reforma las contadurías de Hacienda estableciendo un funcionariado encargado de llevar un libro de caja con la finalidad de dejar constancia de todas las consignaciones reales ${ }^{31}$.

\subsection{Análisis diplomático}

La pieza documental, objeto de la presente publicación, se trata de una carta de venta y privilegio datada en Madrid, el 23 de abril de 1583, por la que Felipe II concede a la población de Arganda la jurisdicción real y el título de villazgo ${ }^{32}$.

Se incoa por la intitulación, solemne, con el nombre del monarca, precedido del tratamiento de cortesía (don) y seguido por la fórmula de derecho divino (por la gracia de Dios) y la expresión de dominio (rey de Castilla, de León, de Aragón, de las Dos Secilias, de Jerusalem, de Portugal, de Navarra, de Granada, de Toledo, de Valencia, de Galicia, de Mallorcas, de Sevilla, de Cerdeña, de Córdova, de Córcega, de Murcia, de Jaén, de los Algarves, de Algezira, de Gibraltar, de las yslas de Canaria, de las Yndias orientales y occidentales, yslas e tierra firme del Mar Océano, archiduque de Austria, duque de Borgoña y de Bravante y Milán,

27 Las escribanías mayores, diversificadas de la Cancillería Real, emiten dos tipos preferentes de documentos: las cartas de privilegio y las cartas de privilegio y confirmación. J. GARCÍA ORO, "Clasificación y tipología documental", en Introducción a la paleografia y la diplomática general, Madrid, 1999, pp. 217-218.

28 P. L. LORENZO CADARSO, El documento real en la época de los Austrias (1516-1700), Cáceres, 2001, p. 41.

29 M. S. MARTÍN POSTIGO, "La cancillería castellana en la primera mitad del siglo XVI", Hispania, 93 (1964), pp. 349-350.

30 A. TAMAYO MACHUCA, Archivística, diplomática y sigilografia, Madrid, 1996, pp. 164-166.

31 M. S. MARTÍN POSTIGO, "Aportación al estudio de la Cancillería Real castellana en la segunda mitad del siglo XVI”, Hispania, 105 (1967), pp. 381-383.

La documentación de los reinados de Felipe III y Felipe IV también fue objeto de atención de esta insigne diplomatista en su estudio: "La Cancillería Real castellana en el siglo XVII", Cuadernos de Historia de España, LXIX (1987), pp. 123-195.

32 Un traslado de esta carta de privilegio fue escriturado el día 1 de enero de 1764. Aparece inserto en un manuscrito de 194 folios, con cubiertas de pergamino (AMAr, sign. 009700360001). 
conde de Abspurgb, de Flandes y de Tirol y de Barcelona, señor de Vizcaya y de Molina, etcétera).

porla gracia oc Bios Rev oe Rattilla oc $\mathrm{Z}$ con oc Aragon oclasoos feciliae oe jerufalem oepo

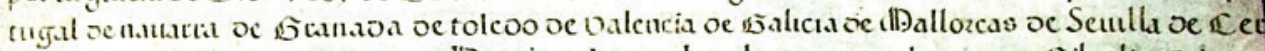

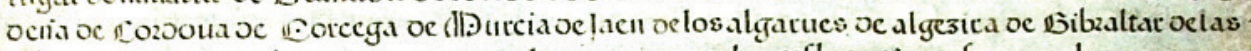

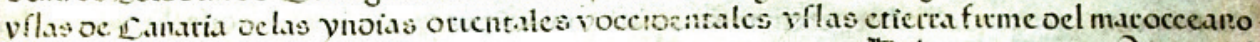

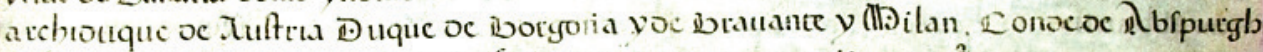
aeflunoes voctitol voe batcelona fenoz oc Otscaya yoemolina ctecêे. D $D$ R quanto.

A continuación, la exposición, que comienza insertando el texto íntegro del breve y letras apostólicas, escritas en pergamino y selladas con su sello de plomo, por el pontífice Gregorio XIII en 1574, mediante el cual se le concede poder y libre autoridad para poder dismembrar, apartar y vender perpetuamente qualesquier villas y lugares, fortalezas, juridiciones, vassallos, montes, bosques y otros heredamientos con sus rentas, derechos y aprovechamientos, pertenecientes en qualquier manera a qualesquier yglesias destos nuestros reynos, cathedrales, aunque sean metropolitanas, collegiales, parrochiales y a qualesquier monasterios, cabildos y conventos y dignidades, ospitales y otros lugares pios, y darlas y donarlas y disponer dellas, no excediendo la renta de las dichas villas y lugares y otros bienes y rentas que ansi dismembráremos y vendiéremos, del valor de quarenta mill ducados de renta en cada un año.

Con la finalidad de traspasar a la Corona Real la jurisdicción de la villa de Arganda (dirección), que hasta entonces lo era de la dignidad arzobispal de Toledo, se dispone que Juan de Salas sea el comisionado de diligenciar todos los tramites, los cuales se siguen recogiendo en la exposición. En primer lugar se le encarga la averiguación de lo que las dichas penas de cámara, pecho forero y las demás rentas pertenecientes a la dicha juridición y señorio y vassallaje avían valido en los cinco años pasados, desde 1574 a 1578, a la vez que conociese el número de vecinos, el cual ascendía a 555 .

En función de este encargo, el comisario determina que el valor que habían rentado las penas de cámara y de sangre, legales y arbitrarias, y otras calumnias y el pecho forero y martiniega y las escrivanías públicas y del concejo de la dicha villa en cada uno de los años citados alcanzaba los 11.621 maravedís y medio; de los cuales se mandó dar y librar una carta de privilegio de juro perpetuo a la dignidad arzobispal de Toledo, en 1580, para que los tenga situados siempre en las alcabalas de la Ciudad Imperial, al tiempo que se la recompensaba con esta cantidad, por ser justa y equivalente, con la condición de que en ningún tiempo se puedan quitar ni redimir en lugar y rrecompensa de lo que ansi le rentavan y valian las rentas y cosas susodichas que el dicho arçobispo tenía en la dicha villa de Arganda y sus términos.

Una vez efectuado lo estipulado, y de lo cual se deja constancia pormenorizada por escrito en el presente documento, se elabora la carta de desmembración, dada en Badajoz el 25 de noviembre de 1580, al tiempo que el concejo, justicia y regimiento de la villa de Arganda es traspasado a la Corona Real, por lo que pasan a tenerla como propietaria, con sus vassallos, términos y juridición civil y criminal, 
alta y vaja, mero mixto imperio, en primera instancia y en grado de apelación, y nos acudiesen con las dichas rentas de penas de cámara y de sangre legales y advitrarias, y las demás rentas anexas y pertenecientes a la dicha juridición, señorio y vassallaje, desde primero de henero de mill y quinientos y ochenta años en adelante.

Todos los autos correspondientes a la citada posesión también son recogidos en la exposición de esta carta de venta y privilegio. De este modo, se incluyen, en forma de acta, todas las diligencias relativas tanto al relevo de los alcaldes e regidores e diputados, alcaldes de la Hermandad, e alguaciles e quadrilleros, escrivanos, e procuradores, e a los demás oficiales puestos en Arganda por la dignidad arzobispal de Toledo, y ahora suplidos con los nombrados por la Corona, como a la prosecución de pleitos carcelarios pendientes y al cambio de diversos aranceles y posturas en establecimientos públicos.

No obstante, para prover y pagar las grandes sumas y cantidades de maravedís que se an gastado en las guerras pasadas assí por la Grande Armada que, de muchos años a esta parte, avemos sustentado así por la mar, contra los turcos enemigos de nuestra santa fee cathólica, como por los exércitos que nos a sido forçoso sustentar por tierra y mar, para defensa de los nuestros estados de Flandes de la imbasión e ympetu de los ereges, y para tener bien armadas las cien galeras que tenemos en la mar contra losdichos enemigos, y para hazer y efetuar otras cosas muy ymportantes para el sustentamiento, guarda y conservación destos reynos y bien universal de toda la cristiandad y defensa della, no bastando para ello nuestras rentas reales por estar embaraçadas y empeñadas, a causa de los muchos y forçosos gastos que se hizieron en tiempo del emperador, mi señor y padre de gloriosa memoria, y en el mío, en las guerras y jornadas pasadas que se an ofrecido en defensa de los dichos nuestros reynos y señorios y de la christiandad, ni los servicios que los dichos mis reynos y señorios en todas partes an hecho y hazen, ni lo que a crecido y augmentádose nuestras rentas reales, ni el oro y plata que se trae de las Yndias, ni lo que se a avido de las cruzadas, subsidios y excusados que nuestros muy santos padres an concedido al emperador y rey, mi señor, y a mí se an tomado y toman a cambio muchas cantidades y sumas de dineros de que devemos y nos corren grandes yntereses, se tomó la decisión de vender a Sebastián de Santoyo, ayuda de Cámara, la jurisdicción de la dicha villa. Sin embargo, el concejo de Arganda solicitó al monarca la rescisión de esa venta y enajenación, manifestando que estavan prestos de nos servir con la misma quantidad que con el dicho Sebastián de Santoyo estava concertado, que era a la dicha razón de diez y seis mill maravedis por cada vezino, y a quarenta y dos mill y quinientos maravedis, el millar de las dichas rentas juridicionales. Una vez vistas las averiguaciones concernientes se resolvió positivamente sobre esta demanda, advirtiéndose de que la cantidad adeudada ascendía a 9.373.914 maravedís. De ahí que fuese otorgada, en septiembre de 1580, carta de venta y privilegio privando de la posesión de la jurisdicción civil y criminal, con sus rentas, a Sebastián de Santoyo, y entregándosela al concejo de Arganda. De nuevo, se ordena que se verifiquen todas las diligencias cumplideras al cambio de propietario, incluyendo, en esta oportunidad, la delimitación de su territorio, lo que se llevó a efecto durante el año 1581: La qual dicha mojonera de los dichos términos $<$ de $>$ la dicha villa de Arganda y de las demás villas y lugares con quien confina, de suso declarados, se hizo por el dicho licen- 
ciado Francisco de Morales, nuestro juez de comisión, según y de la manera que de suso va declarado, se dio la posessión de la juridición dellos al dicho concejo de la dicha villa de Arganda.

Más adelante, por cédula real, fechada en Lisboa el 21 de mayo de 1582, se dispone que se haga entrega de los citados maravedís al Consejo de Hacienda por parte de la villa de Arganda, lo cual se efectúa y, consecuentemente, se extiende la carta de pago, dada el 7 de febrero de 1583 en Madrid: De los quales dichos nueve quentos y trecientas y setenta y tres mil y novecientos y catorze maravedis, me doy por contento y pagado a toda mi voluntad, por quanto el dicho nuestro thesorero general los recivió en reales de contado en nuestro nombre.

Asimismo, en la disposición de esta carta de venta y privilegio se estipula que en adelante se pueda intitular "Arganda del Rey": Y os hago villa de por sí y sobre sí, y lo seays y os llameys e yntituleys así para que, en la dicha villa y en los dichos sus términos y juridición y dezmería, uséis y exerçáis nuestra juridición civil y criminal, alta y vaxa, mero mixto imperio, según y cómo lo hazía la dicha dignidad arçobispal y arçobispo de Toledo en la dicha villa de Arganda, y podáis poner y pongáis, y tener y tengáis, en la dicha villa y sus términos para execución de la justicia, horca, picota, cuchillo, cárcel, cepo, açote y todas las otras insignias de jurisdición que se suelen y pueden tener y fueren necesarias para lo suso dicho, con las dichas rentas juridicionales y cosas annexas al señorio y vasallaje y jurisdición de la dicha villa de Arganda. Igualmente, Felipe II, constituyéndose en tenedor y poseedor suyo, no sólo le cede, renuncia y traspasa todo el derecho y ación, título y recurso, que avemos y tenemos y nos pertenece, conpete, y puede competer y pertenecer en qualquier manera y por qualquier razón que sea, o ser pueda, a todo lo susodicho y cada cosa y parte dello, sino que también le entrega el señorío, propiedad y posesión real, corporal y cevil y natural, vel casi de todo ello, y quiero y es mi voluntad que la dicha posessión se traspase y continúe con vosotros, sin que aya intervenido ni intervenga para ello auto ninguno de aprehensión de posesión, y le da poder y entera facultad para que podáis elegir y nombrar en cada un año alcaldes ordinarios y de la Hermandad, regidores, alguaziles, procuradores y escrivanos del número y concejo y otros oficiales que fueren necesarios, como viéredes que más conviene a la buena governación de la dicha villa, y pongáis y elijáis vuestras guardas y que, eligidos y nombrados los dichos oficiales, usen sus oficios con ella y sus términos y juridición, y hagan justicia conforme a las leyes destos reynos, sin que nos, ni los reyes nuestros succesores, confirmemos y aprovemos la dicha eleción, haziéndose como se acostumbra y deve hazer de derecho; a los quales dichos alcaldes doy poder y entera facultad para que usen $y$ exerçan la dicha jurisdición cevil y criminal, alta y vaxa, mero mixto imperio, entera y cumplidamente en esa dicha villa de Arganda y en los dichos sus términos y jurisdición, en mi nombre, y de los reyes nuestros sucessores, y que de las sentencias que se dieren de diez mill maravedis avaxo en lo civil, se apele para el regimiento de la dicha villa, y de diez mill maravedís arriva, se apele y pueda apelar para ante el presidente y oydores de la nuestra Audiencia y Chancillería, que reside en la villa de Valladolid, como se haze y deve hazer en las demás villas destos reynos que tienen juridición por sí e sobre sí. Por último, también se establece que tanto él, como otros reyes sucesores suyos, no puedan vender ni añadir en la dicha villa, ni en sus términos, regidores ni alguaziles ni escrivanos ni diputados ni fieles 
executores, guardas de montes, ni otro ningún oficio de concejo, por venta ni en otra manera alguna; y otrosí, os damos la dicha juridición con que el alcalde mayor de la dicha dignidad, ni otras ningunas justicias de qualesquier partes que sean, no puedan entrar ni entren en la dicha villa ni sus términos a os citar, llamar ni emplazar ni hazer parecer ante sí a ningún vezino de la dicha villa de Arganda, sin embargo de qualesquier costumbres, ordenanças o concordias que aya entre la dicha villa y otras partes.

Con la finalidad de hacer más efectivo y garantizar lo determinado en la disposición, se incluyen diversas cláusulas de naturaleza sancionativa: obligatorias, renunciativas, prohibitivas, derogativas, penales, preceptivas y emplazatorias (...la qual derogamos y damos por ninguna y de ningún valor y efeto, antes queremos que se guarde esta dicha nuestra carta de venta y previllegio y merced, como en ella se contiene y queremos que valga, bien ansí como si fuese hecha espresa minción en particular de las dichas concordias o costumbres, aunque en ellas ubiese cláusulas derogatorias, las quales, e aqui por expresadas, como si de verbo ad verbum fuesen puestas, y ansí lo concedemos de nuestro propio motuo y cierta ciencia y poderío Real absoluto de que en esta parte quiero usar y uso como rey y señor natural destos reynos... y que no yremos ni vernemos, ni hirán ni vernán, ni consentiremos yr ni venir ni pasar contra ella ni contra alguna cosa ni parte de lo en ella contenido, agora ni en tiempo alguno, para siempre jamás y que, por más ni por menos, ni por el tanto, y aunque sea dado y prometido mayor de suma de maravedis, de presente ni en tiempo alguno, ni por otra causa ni razón alguna que sea o ser pueda, pensada o no pensada, o que de nuevo sobrevenga a nos, y a los reyes nuestros sucesores, perteneciere y puede pertenecer, direte o indirete, por algún título o causa, no vos será quitada ni enbargada cosa alguna de lo en esta carta contenido, aunque se diga que se recivió lesión ynnorme ni ynnormísima, o otro daño o engaño por muy grande que sea, y que la dicha dismembración no se pudo ni devió hazer, y que huvo en ello defeto de causa o de orden o forma o sustancia o solemnidad alguna requerida, de derecho y de uso y costumbre, o en otra qualquier manera. Y obligo a mí, y a los reyes mis sucesores, y prometo por mi y por ellos, que os será cierta, sana y de paz la dicha jurisdición y cosas de suso declaradas, asi en este previlegio y carta de venta como en la dicha capitulación y asiento contenidas, y qualesquier cosas y parte dello, para que lo gozéis perpetuamente para siempre jamás, como dicho es, quieta y pacíficamente, sin contradición alguna, y que nos, ni los reyes nuestros sucessores, agora ni en tiempo alguno, no venderemos ni empeñaremos, donaremos, trocaremos ni enaxenaremos, sacaremos ni apartaremos de nuestra Corona y Patrimonio Real la dicha villa de Arganda ni su juridición y término, ni la daremos a príncipe, reyna ni infante, ni encomienda, ni yglesia, ni monasterio, ni a persona alguna de qualquier calidad y condición que sean, en ninguna manera, aunque nos quieran dar y pagar los maravedís que la dicha villa nos dio y pagó, ni otra mayor cantidad...; e que si la diéremos, vendiéremos o enaxenáremos la tal venta, donación y enaxenación sea en sí ninguna y de ningún valor y efeto, y que en qualquier tiempo que lo susodicho acaeciere, o sobre la dicha juridición y señorío y cosas que asi os vendo, o sobre qualquier cosa y parte de lo en esta escriptura contenido, y de lo a ella annexo y perteneciente y dependiente en qualquier manera a la dicha villa, vezinos y moradores della, fuere puesto pleito o impedimento o controversia o embaraço alguno, 
de hecho o de derecho, nos, y los reyes que después de nos fueren, y nuestros herederos y sucesores, mandaremos tomar la voz del pleito para que se defienda a nuestra costa hasta lo fenecer y acavar y pacificar y asegurar para que os sea todo cierto, seguro y de paz, y lo tengáis y poseáis libre y pacíficamente, sin contradición alguna...; y que nos, ni los reyes nuestros sucesores, no diremos ni alegaremos que no nos fue fecho saver en tiempo, ni alegaremos excepción ni remedio que aya en nuestro favor para lo aver y tener y guardar y cumplir todo lo susodicho, $n i$ yr ni venir contra ello, antes quiero que todavía lo contenido en esta carta y capitulación valga, y en todo me obligo a la evición y saneamiento dello y de cada cosa y parte dello, y prometo por mí, y los reyes nuestros sucesores, que no os siendo cierta y segura y de paz la dicha jurisdición y rentas y cosas en esta escriptura contenidas, y qualquier cosa y parte della, y lo a ella annexo y perteneciente en qualquier manera, que nos, y nuestros sucesores en estos nuestros reynos, os daremos todos los maravedís que asi dais y pagáis por todo ello con el doblo, con más las costas y gastos e yntereses y menoscavos que sobrello se os siguieren y recrescieren, por nombre de propio interese convencional que sobrello con vos pongo, y que para esto no ayáis de esperar, ni esperéis, que la cosa os sea sacada ni quitada, sino que movido el dicho pleito, sacada o no sacada, podáis pedir y demandar a nos, o los reyes nuestros sucesores, que mandemos tomar la voz dello y seguirlo a nuestra propia costa costa (sic), como dicho es. Y que seamos obligados de lo hazer y cumplir, so la dicha pena que en quanto a esto la e por repetida, y la pena pagada o no pagada que todavía yo y mis sucesores seamos obligados a vos hazer ciertas, sanas y de paz la dicha juridición, rentas y derechos, y otras cosas de suso declaradas, y cada una cosa y parte dello, y vos pagaremos las costas y daños, yntereses y menoscavos que sobrello se os siguieren y recrescieren... $Y$ para más validación y firmeza de todo lo que dicho es, y de cada cosa y parte dello, y para que aya efeto todo lo en esta carta contenido, aviendo aqui por insertas, de palabra a palabra, todas y qualesquier leyes, asi de ordenamiento como de partida, fueros, pregmáticas y estilos, y qualesquier derechos, usos y costumbres, contratos, previllegios generales y particulares, y todas y qualesquier leyes, estatutos y establecimientos, prescriciones y todos otros remedios y qualesquier cláusulas especiales y generales, aunque sean derogatorias, de lo que fuere o pudiere ser en contrario de lo que dicho es y de lo en esta carta contenido, para que no valga ni se pueda yr ni venir contra ello, en qualquier manera que sea o ser pueda, y en quanto es necesario para que lo contenido en esta carta valga y sea firme para siempre jamás, las reboco, abrogo y derogo y doy por ningunas, y de ningún valor y efeto, en quanto son o pueden ser en contrario de lo susodicho y de qualquier cosa y parte dello. Y quiero y es mi voluntad que las dichas leyes y remedios, ni otra cosa alguna de lo que dicho es, no pueda impedir ni impida el efeto y cumplimiento y seguridad de lo en esta carta contenido, ni cosa alguna de lo que dicho es y, especialmente, derogo la ley fecha por el rey don Juan, el segundo, en las Cortes que tuvo en la villa de Valladolid el año de mill y quatrocientos y quarenta y dos, en que se contiene la solemnidad que a de intervenir en las donaciones y enaxenaciones que el rey haze, y otras qualesquier leyes que prohiben la enagenación de los bienes del patrimonio y preheminencia Real..., y de todas las otras leyes, remedios y derechos que especialmente se ayan de renunciar, los e aqui por especial y expresamente renunciadas y derogadas, y las caso y anulo de mi propio motuo y 
cierta sciencia y poderío Real absoluto para que, lo que ansí os vendo y traspaso y hago donación de todo lo en esta carta con tenido, sea válido, cierto y firme para siempre jamás... Y renunciamos y apartamos de nos, y de nuestros herederos y succesores, qualesquier cosa que contra esto pueda ser, y qualesquier provisiones y establecimientos, previlegios, usos y costumbres y prescripciones, de que no aya memoria en contrario, y otras qualesquier leyes y derechos que en contrario sean o ser puedan y, especialmente, renuncio la ley y derecho que dize que general renunciación de leyes fecha non vala, y mando a todos y qualesquier nuestros fiscales, que son o fueren ansí del nuestro Consejo Real como de nuestras Chancillerías, que no contradigan, pidan ni demanden en juizio, ni fuera del, agora ni en tiempo alguno, cosa alguna de lo contenido en esta carta de venta y escriptura, ni parte dello, y que, desde agora para entonces, no les quede ni tengan poder ni facultad para lo poder hazer; y ansimismo mandamos a los del nuestro Consejo Real y a los presidentes y oydores de las nuestras Audiencias, alcaldes de nuestra Casa y Corte y Chancillerías, governadores, corregidores, alcaldes y otras justicias, asi a los que agora son como a los que serán de aquí adelante, en los dichos nuestros reynos y señorios, que no consientan a los dichos fiscales del Consejo Real y Chancillerías que, en juizio ni fuera del, contradigan, pidan ni demanden a vos, el dicho concejo de la dicha villa de Arganda, cosa alguna, ni los oygan sobre ello, que nuestra voluntad es que no se pueda proceder, ni proceda, en cosa alguna contra esta dicha carta y lo en ella contenido, y los ynivo, y he por hinividos, del conocimiento dello, por manera que no les quede ni finque juridición alguna cerca desto, ni la tengan adelante en qualquier tiempo que lo tal acaeciere, pero todavía, y en todo tiempo, les mando que juzguen en todo y por todo, conforme a esta dicha escriptura y previllegio, y en guarda y conservación y execución de todo lo en ella contenido, y cada cosa y parte dello, y todo lo que en contrario se hiziere sea en sí ninguno, y desde agora lo he y declaro por tal. Y otrosí, encargamos al serenísimo príncipe don Diego, nuestro muy caro y muy amado hijo, y mando a los infantes, duques, marqueses, condes, ricos hombres, maestres de las órdenes, priores, comendadores, alcaydes de los castillos y casas fuertes y llanas, y a los del mi Consejo, preseidente y oydores de las nuestras Chancillerías, alcaldes de la nuestra Casa y Corte y Chancillerías, y a todos los asistentes, coregidores, alcaldes de sacas, governadores, alcaldes, alguaziles, merinos, prebostes, concejos, justicias, regidores, cavalleros, escuderos, oficiales y hombres buenos de qualesquier ciudades, villas y lugares destos nuestros reynos y señorios, asi a los que agora son como a los que serán de aqui adelante, e a cada uno y qualesquier dellos en su juridición, que os guarden y cumplan, y hagan guardar y cumplir, esta carta de venta y todo lo en ella contenido, en todo y por todo, según y cómo en ella se contiene y declara; $y$ contra el tenor y forma della, ni contra cosa alguna ni parte dello en ella contenido, vos no vayan ni pasen, ni consientan yr ni pasar, en tiempo alguno, ni por alguna manera, ni oygan ni conozcan en cosa alguna contra lo susodicho, y cada cosa y parte dello, contra ese dicho concejo y villa de Arganda por alguna manera, y lo remitan a nos y a los del nuestro Consejo Real, que yo por la presente los ynivo, y he por ynividos, de todo lo susodicho y de cada cosa y parte dello... Y si vos, el dicho concejo, justicia y regidores, oficiales y hombres buenos de la villa de Arganda, quisiéredes nuestra carta de previllegio desta dicha carta de venta y de lo en ella contenido, mando a mis contadores mayores y a los otros 
oficiales que están a la tabla de los mis sellos, que os la pasen y sellen a vos y a los que después de vos fueren, la más fuerte, firme y vastante que les pidiéredes y menester oviéredes en la dicha razón, sin os pedir ni llevar por ello diezmo ni chancillería, ni otros derechos, pues esta venta y de las ventas que se an hecho por nos, no se an acostumbrado pagar los dichos derechos, e sin que os pongan en ello enbargo ni inpedimento alguno, y los unos ni los otros no fagades ni fagan ende al por alguna manera, so pena de la nuestra merced y de diez mil maravedís para la nuestra Cámara y fisco, a cada uno por quien fincare de lo asi hazer y cumplir; y demás mando al home que esta carta, o su traslado signado de escrivano público, mostrare que los emplaze que parezcan ante nos, en nuestra Corte, desde el día que los emplazare hasta quinze dias primeros siguientes, so la dicha pena, so la qual mandamos a qualquier escrivano público que para esto fuere llamado, que dé al que se la mostrare testimonio signado con su signo, porque yo sepa cómo se cumple mi mandado; y mandamos que tomen la razón desta carta Juan Bernardo, nuestro contador, y Juan López de Vibanco, nuestro criado, para hazer cargo al dicho nuestro thesorero general de los dichos nueve quentos trezientas y setenta y tres mil y ochocientos y catorze maravedis).

Del mismo modo, el cuerpo de esta carta de venta y privilegio se cierra con la inserción de las cláusulas corroborativas, mediante las que se anuncia expresamente que se han cumplido las formalidades exigidas para que tenga fuerza legal: De lo qual mandé dar, y dimos, a vos el dicho concejo, justicia y regidores, oficiales y ombres buenos de la dicha villa de Arganda, esta mi carta, escripta en pergamino, y firmada de nuesta mano, y sellada con nuestro sello de plomo pendiente en filos de seda a colores, y librada de los del dicho nuestro Consejo, y refrendada del dicho Pedro Descovedo, nuestro secretario.

\section{y ferenta yeres mil yocbocientos veatorzemaraucois Deloqual manoc aar younos auos clobs.

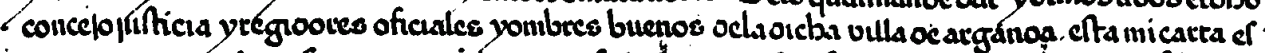

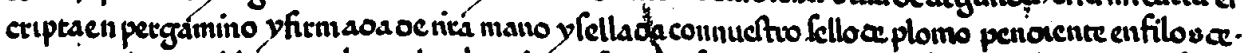

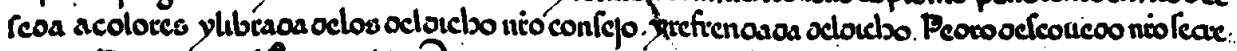

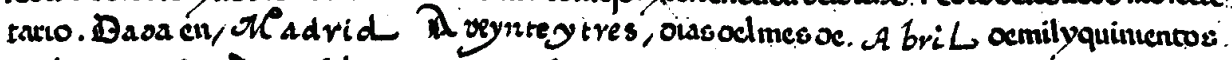

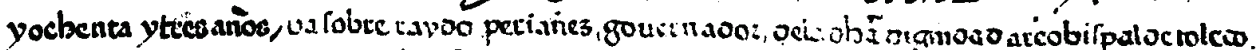

El escatocolo comprende la data y la validación. La fecha es completa, es decir tanto tópica como cronológica: Dada en Madrid, a veynte y tres días del mes de abril de mil y quinientos y ochenta y tres años. Por su parte, la validación está compuesta por la firma autógrafa del monarca, el refrendo del escribano (Yo Pedro Descovedo, secretario de su Magestad cathólica, la fize escrivir por su mandado rúbrica-), las suscripciones del chanciller, registrador y otros oficiales menores cancillerescos y, en su momento, el sello de plomo, que en la actualidad no se conserva $^{33}$.

33 Sólo se mantienen trozos del lemnisco que unía esta pieza documental y el sello de plomo, el cual era un cordón de seda trenzado, a colores amarillo, rojo, blanco y azul. 


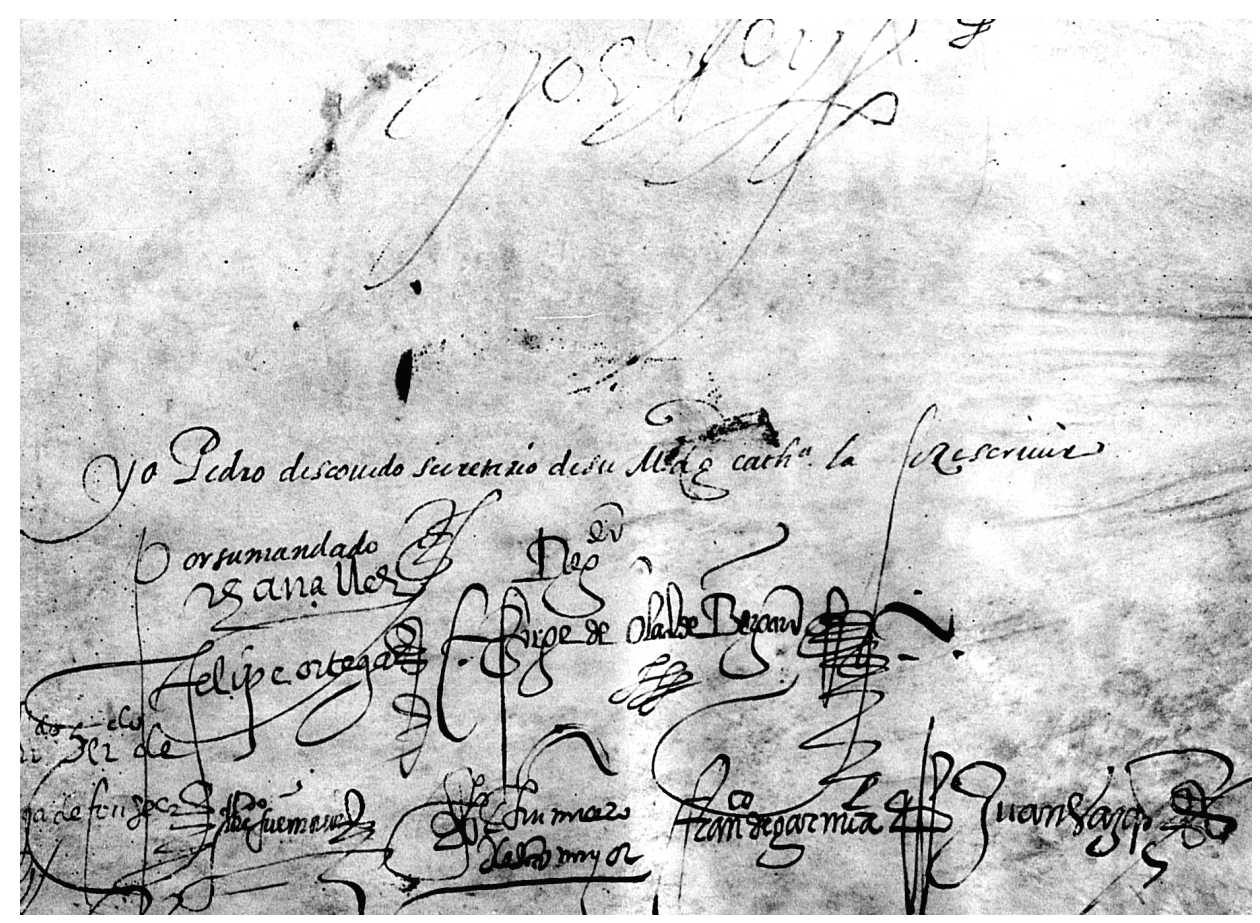

De igual forma, hay que significar que esta carta también incluye el brevete (Vuestra Majestad, en virtud del breve y facultad appostólica que tiene de su Santidad, dismembra de la dignidad arçobispal de Toledo e incorpora en su Corona Real la villa de Arganda y le asegura y promete que no será apartada della, y le da juridición çivil y criminal, alta y baxa, mero mixto imperio por nueve quentos trescientos y setenta y tres mil y ochocientos y catorce maravedis, que en ello montó) y la toma de razón, efectuada por Juan Bernaldo y Juan López de Vibanco en Valladolid, el 13 de agosto de 1592, por la cantidad de 182 reales.

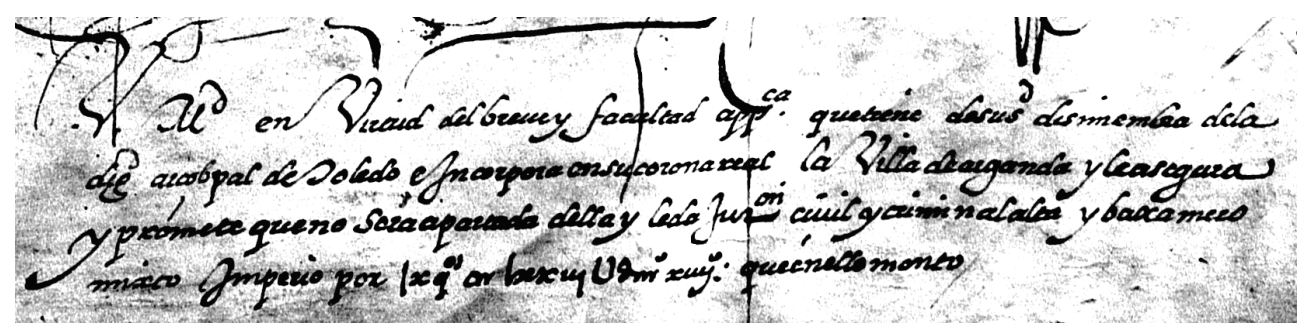




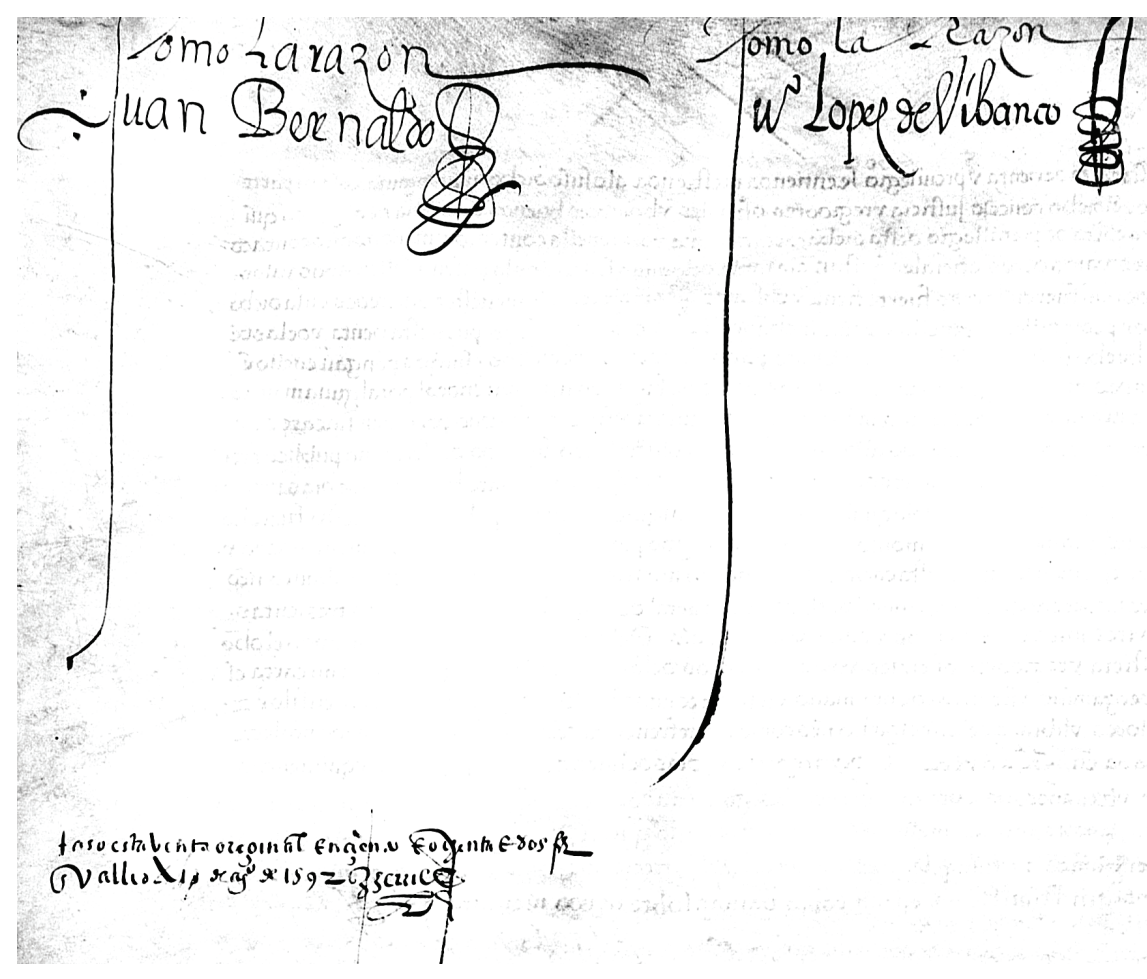

Finalmente, se puede mencionar que esta carta de privilegio, hace poco restaurada, se cerraba mediante tiras de seda, rojas y amarillas, las cuales enlazaban la cubierta y de las que, al presente, tan sólo se conservan algunos fragmentos. 